\title{
Pengaruh Pemberian ASI Eksklusif, PHBS dan Kepadatan Penduduk terhadap Kejadian Diare pada Balita di Kota Surabaya Tahun 2018
}

\section{The Effect of Exclusive Breastfeeding, PHBS And Population Density on The Incidence of Diarrhea in Toddlers Surabaya City At 2018}

\author{
Ruri Indra Ramadani ${ }^{1}$
}

\begin{abstract}
ABSTRAK
Latar Belakang: Anak-anak merupakan aset suatu bangsa, karena setiap bangsa yang ada di bumi selalu bergantung dengan tunas-tunas muda baru sebagai generasi penerus yaitu anak-anak. Faktor kesehatan salah satunya yang merupakan faktor yang penting dalam tumbuh kembang anak-anak. Diare salah satu yang rentan menjangkiti anak-anak dimana penderita diare akan menderita dehidrasi dan malnutrisi yang berat kemudian jika tidak di tangani akan menghambat tumbuh kembang anak bahka tidak jarang terjadi kefatalan. Angka diare di Kota Surabaya masih menduduku peringkat ke 3 ter tinggi di Jawa Timur, sehingga peneliti tergugah untuk dan melakukan penelitian ini dengan

Tujuan: Tujuan yaitu menganalisis pengaruh pemberian Asi Eksklusif, PHBS dan kepadatan penduduk terhadap kejadian diare pada balita di kota surabaya.

Metode: metode penelitian kuantitatif - crossectional,

Hasil: Hasil utama dari analisis regresi berganda Kepadatan_Penduduk 0,099, Asi_Exklusif 0,006 dan Rumah tangga_Berphbs 0,432.

Keismpulan: Kesimpulan dari penelitian ini yaitu Asi Eksklusif mempengaruhi kejadian diare pada balita di surabaya pada tahun 2018, setiap penambahan 1\% dari total ibu yang memberikan Asi Eksklusif pada balitanya di Kota Surabaya maka akan mengurangi angka kejadian diare pada balita sebanyak 16 balita.
\end{abstract}

Kata kunci: diare, balita, surabaya

\section{ABSTRACT}

Background: Children are an asset of a nation, because every nation on earth always depends on new young shoots as the next generation, namely children. Health factors, one of which is an important factor in children's growth and development. diarrhea one that is vulnerable to infecting children where diarrhea sufferers will suffer from dehydration and severe malnutrition then if not treated will inhibit the growth and development of children even fatality.

Objectives: The number of dysentery in Surabaya still ranks as the third highest in Westjava, researchers were intrigued to made this research with the aim to analyzing what effect of giving exclusive breastfeeding, PHBS and population density on the incidence of diarrhea in infants on Surabaya.

Methods: Quantitative - cross-sectional research methods,

Results: The main results of the multiple regression observation Population_Density 0.099, Asi_Exclusive 0.006 and Phbs_Household 0.432.

Conclusion: The conclusion from this study are Asi exclusively affects the incidence of diarrhea in toddlers on Surabaya at 2018, each addition of $1 \%$ of total mothers who give exclusive breastfeeding to their toddlers in the city of Surabaya will scale down the incidence of diarrhea in infants of 16 toddlers.

Keywords: diarrhea, toddlers, surabaya

\footnotetext{
*Korespondensi:

rurindra@gmail.com

Ruri Indra Ramadani

${ }^{1}$ Departemen Epidemiologi, Biostatistika dan Kependudukan, dan Promosi Kesehatan dan Ilmu Perilaku, Fakultas Kesehatan Masyarakat, Universitas Airlangga, Kampus C Mulyorejo, 60115, Surabaya, Jawa Timur, Indonesia
} 


\section{PENDAHULUAN}

Suatu negara dan bangsa sangat mengandalkan generasi selanjutnya sebagai penerus tongkat estafet, akan tetapi generasi tersebut yaitu anak-anak masih lemah dan belum setabil baik dari sisi jasmani dan rohani. Untuk jadi negara yang kuat, berdaulat dan sejahtera adalah impian bagi negara yang terdapat di peta dunia. Semua dapat diwujudkan jika sebuah negara memiliki pondasi dan kompetensi yang mumpuni pada bidang-bidang yang lain untuk bersaing dengan negara lain seperti pada bidang edukasi, teknologi, ekonomi dan kesehatan. Bidang kesehatan pada umumnya menjadi sorotan utama baik pada dewasa terlebih lagi anak-anak sebab pada masa Tumbang (tumbuh kembang) anak-anak masih sangat rentan terganggu kesehatanya sehingga mudah sekali terjangkit suatu penyakit karena penyakit sangat mudah menular dan menyebar, sehingga bidang kesehatan sudah mestinya menjadi consern utama.

Diare pada rentang usia anak-anak atau balita masih sering terjadi hal ini di sebabkan berbagai macam faktor seperti lingkungan, bakteri dan virus.

Menurut (Sutomo, 2010) balita merupakan istilah untuk anak umur 1 sampai 3 tahun dan 3 sampai 5 tahun (anak pra sekolah). Kegiatan penting seperti makan, BAB, BAK, dan personal hygiene pada bayi umur tiga tahun masih bergantung pada pengasuh. Pada tahap ini pertumbuhan kemampuan berbicara mulai bertambah begitu juga kemampuan melangkah. Meskipun demikian kebisaan untuk dalam hal lain masih kurang.

Tahun 2015 di Kota Surabaya terjadi peningkatan kejadian diare, terdapat kejadian diare yang terjadi dan ditangani sebanyak 16.234 jiwa pada balita, kejadian tersebut merupakan kasus yang terdapat di seluruh kecamatan yang ada di Kota Surabaya, sedangkan untuk kasus diare secara keseluruhan berdasarkan data Dinas Kesehatan Kota Surabaya, terdapat kasus yang di tangani sebesar 65.447 dari perkiraan kasus sebanyak 60.960 kejadian. (Dinkes Kota Surabaya, 2015)

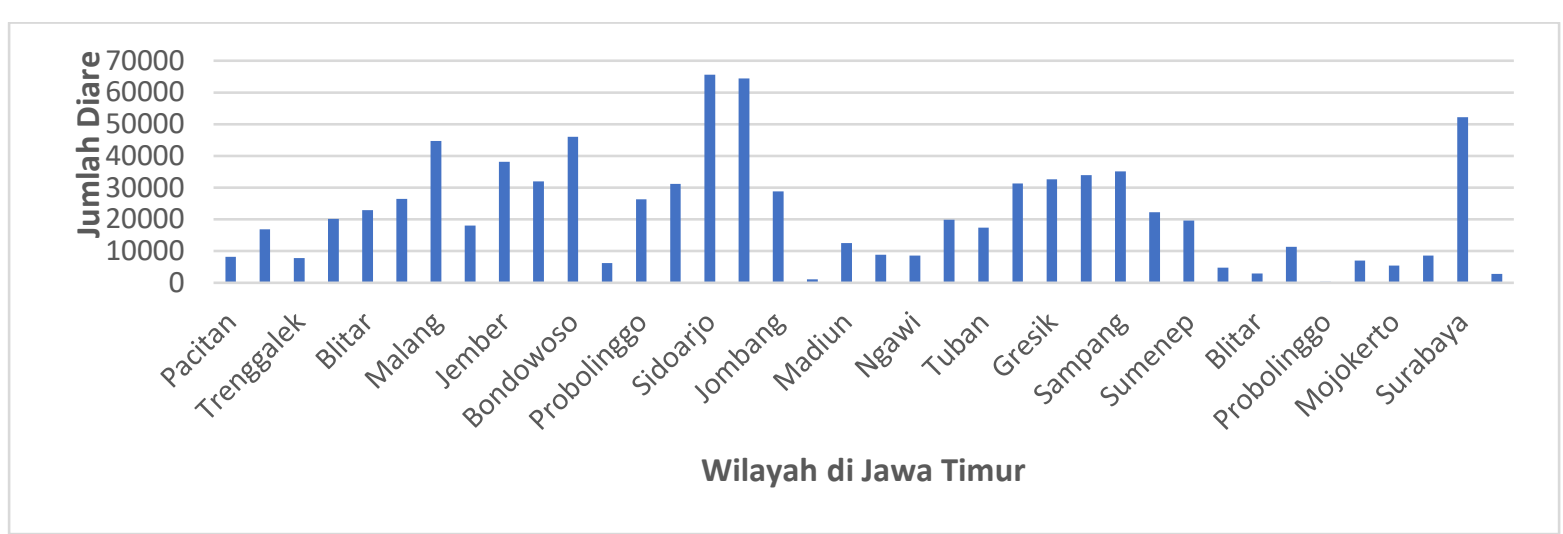

Gambar 1. Diare di Jawa Timur

Berdasarkan “Jumlah Kasus Penyakit Menurut Kabupaten/Kota dan Jenis Penyakit di Provinsi Jawa Timur 2018" di sadur melalui Badan Pusat Statistik Provinsi Jawa Timur, pada 38 wilayah yang berada di Jawa Timur, kabupaten yang memiliki kejadian dengan angka diare terbanyak di Provinsi Jawa Timur adalah kabupaten Sidoarjo dengan jumlah sebanyak 65.543 ribu penderita. Kemudian di peringkat nomor dua ada kabupaten Mojokerto dengan jumlah 64.468 ribu penderita. Kota Surabaya sendiri berada di peringkat ke tiga terdapat jumlah kasus sebanyak 52.258 ribu penderita (Badan Pusat Statistik Provinsi Jawa Timur, 2019).

Sejak 2010 hingga tahun 2018 di Kota Surabaya angka kejadian diare secara berurutan dimulai pada tahun 2010 terdapat sejumlah 120.008 penderita, pada tahun 2011 terdapat 101.318 penderita, pada tahun 2012 terdapat 92.072 jumlah penderita, pada tahun 2013 terdapat 95.105 ribu penderita, pada tahun 2014 terdapat 86.893 ribu penderita, Pada tahun 2015 terdapat 65.447 ribu penderita, Pada tahun 2016 terdapat 60.627 ribu penderita, Pada tahun 2017 terdapat 76.602 ribu penderita, Pada tahun 2018 terdapat 78.463 ribu penderita (Dinas Kesehatan Kota Surabaya, 2018).

Diare ialah penyakit yang memiliki hubungan erat dengan saluran pencernaan, biasanya penderita diare memiliki BAB cair atau melembek, BAB menjadi lebih sering yaitu lebih dari 3 kali dalam sehari. Diare pada anak-anak bisa menyebabkan hal yang fatal jika tidak di imbangi dengan input cairan dan nutrisi yang baik atau diare mendadak terjadi dan tidak mendapatkan perawatan yang tepat oleh pengasuh, sebaliknya diare sebenarnya juga termasuk penyakit yang ringan jika penderita mendapatkan perawatan yang memadai.

Tahun 2014 Imelda Mohamad, melakukan riset sehingga memperoleh kesimpulan bahwa Indonesia dan negara berkembang lainya memiliki persamaan untuk diare masuk sebagai 4 penyakit penyebab utama kematian pada balita, faktor kemampuan pemberian ASI oleh pengasuh/orangtua dalam hal ini Ibu yang tidak mencukupi untuk kebutuhan sang bayi sangat mempengaruhi terjadinya angka diare dan kematian akibat diare, sehingga 
dalam rangka melakukan penurunan angka kejadian dan kematian yang di akibatkan oleh diare perlu di lakukan secara berkesinambungan dengan promkes (promosi kesehatan) mengenai pemberian ASI oleh pengasuh dan Perilaku Hidup dan Sehat (Mohamad, Abdullah and Prawirodiharjo, 2014), kemudian penelitian lain penelitian yang di lakukan oleh Amalia memberikan kesimpulan hubungan antara kepadatan penduduk, secara spasial mengindikasikan terdapat hubungan antara variabel tersebut terhadap angka diare. Bisa di ketahui berdasarkan sejalannya hasil penelitian dengan penelitian lain atau teori yang mendasari (Amalia, 2012).

Sustainable Development Goals atau SDGs di rumuskan oleh dewan PBB (Perserikatan Bangsa-Bangsa) dan di promosikan untuk menjadi tujuan dunia sebagai pembangunan berkelanjutan, program ini adalah kelanjutan dari program sebelumnya yang pada tahun 2015 telah berakhir yaitu Millenium Development Golas atau MDGs, aspek kesehatan adalah pondasi utama sebuah negara dalam melakukan pembanguanan, melalui program SDGs pemerintah dapat memperbaiki dan meningkatkan kualitas kesehatan pada balita, seperti yang terdapat pada program SDGs target hingga tahun 2030, pada tujuan ke tiga yaitu menargetkan berkurangnya kematian pada angka bayi baru lahir menjadi 12 per 1000 kelahiran bayi hidup dan kematian anak balita 25 per 1000 kelahiran balita hidup (United Nations, 2015).

Surabaya adalah kota metropolitan ke 2 di Indonesia, Kota Surabaya memiliki tumbuhan rindang di sekitaran jalan-jalan yang ada hampir di setiap trotoar selain itu tata ruang Kota juga bagus, penghargaan yang sering di peroleh Kota Surabaya yaitu sebagai kota metropolitan terbersih nomer 1 di Indonesia sebanyak 8 kali secara paralel (Pipit, 2019).

Kota Surabaya selain hal yang telah di suratkan di atas mulai tahun 2012 memiliki capaian yang bagus dalam berbagai hal seperti keanekaragaman hayati, sosial, ekonomi, perubahan iklim, pengendalian pencemaran udara dan pencemaran air, sayangnya capaian diatas belum berbanding lurus dengan masih banyak di jumpainya kasus diare di Kota Surabaya.

Atas dasar uraian diatas peneliti ingin mengetahui pengaruh PHBS, Asi Eksklusif dan kepadatan penduduk terhadap kejadian diare terhadap bayi umur tiga tahun di kota surabaya.

\section{METODE PENELITIAN}

Penelitian ini adalah penelitian data sekunder jenis yang di gunakan adalah non reaktif, jika berdasar waktu penelitian ini termasuk cross sectional, Sedangkan berdasarkan tujuan dan sifat masalah termasuk penelitian analitik dengan pendekatan observasional.

Penelitian ini dilaksanakan di DKK Surabaya dengan rentang kurang lebih selama 1 bulan.

Populasi penelitian adalah jumlah penduduk yang tinggal di kota surabaya, besar sampel penelitian merupakan penderita diare pada balita pada Kota Surabaya yang terdiri dari 31 kecamatan, sampel di ambil dari data sekunder yang terdapat di SIK berupa Profil Dinas Kesehatan Surabaya.

Variabel penelitian Y merupakan penderita Demam Derdarah Dengue di Kota surabaya, X1 Asi Eksklusif, X2 PHBS dan X3 kepadatan penduduk, Metode pengumpulan data melalui observasi, Data di ambil dari data base dokumen SIK Dinas Kesehata Surabaya Tahun 2018, berupa data kuantitatif yang meliputi diare balita, cakupan pemberian ASI, PHBS dan kepadatan penduduk di 31 kecamatan yang berada di wilayah Kota Surabaya dan analisis data menggunakan software komputer SPSS.

\section{HASIL DAN PEMBAHASAN}

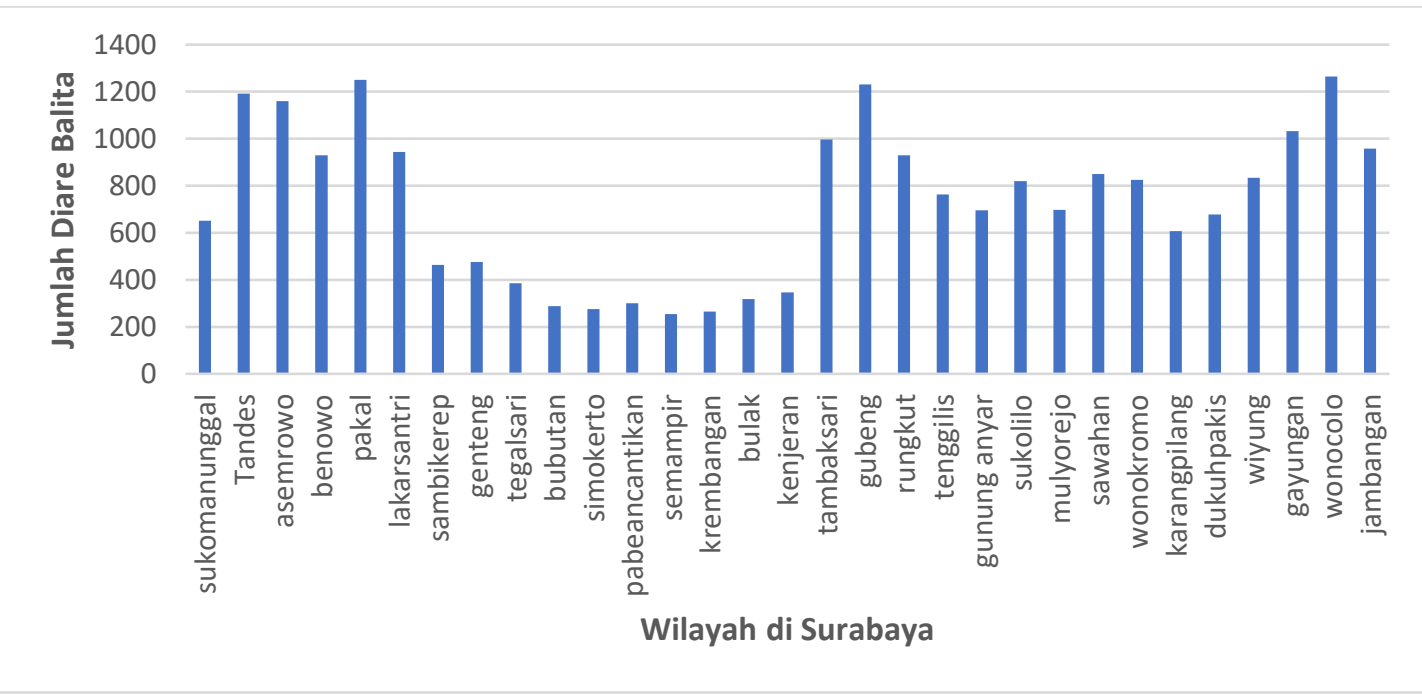

Gambar 2. Diare Pada Balita di Surabaya 
Berdasarkan analisis deskriptif yang dilakukan distribusi angka kejadian perwilayah berbeda-beda. wilayah dengan diare terbanyak adalah Wonocolo dengan 1265 penderita, nomer dua terbanyak adalah Pakal dengan 1250 penderita dan yang ketiga adalah Gubeng dengan 1230 penderita.

Tabel 1. Variabel Yang diolah

\begin{tabular}{|c|c|c|c|c|}
\hline Kecamatan & $\begin{array}{c}\text { Kepadatan } \\
\text { Penduduk } \\
\text { (jumlah) }\end{array}$ & $\begin{array}{c}\text { Diare pada } \\
\text { balita } \\
\text { (jumlah) }\end{array}$ & $\begin{array}{c}\text { Pemberian Asi } \\
\text { Exklusif(\%) }\end{array}$ & $\begin{array}{c}\text { Rumahtangga } \\
\operatorname{Berphbs}(\%)\end{array}$ \\
\hline Sukomanunggal & 10669 & 651 & 80 & 66 \\
\hline Tandes & 8022 & 1192 & 90 & 79 \\
\hline Asemrowo & 2929 & 1159 & 70 & 66 \\
\hline Benowo & 2537 & 929 & 86 & 94 \\
\hline Pakal & 2339 & 1250 & 86 & 58 \\
\hline Lakarsantri & 3371 & 943 & 76 & 60 \\
\hline Sambikerep & 2949 & 464 & 83 & 59 \\
\hline Genteng & 14408 & 475 & 82 & 92 \\
\hline Tegalsari & 23421 & 386 & 72 & 44 \\
\hline Bubutan & 25946 & 287 & 62 & 87 \\
\hline Simokerto & 37194 & 276 & 68 & 63 \\
\hline Pabeancantikan & 11740 & 301 & 61 & 62 \\
\hline Semampir & 21380 & 255 & 62 & 56 \\
\hline Krembangan & 13925 & 264 & 63 & 63 \\
\hline Bulak & 7212 & 318 & 51 & 61 \\
\hline Kenjeran & 18184 & 346 & 65 & 58 \\
\hline Tambaksari & 24374 & 997 & 77 & 68 \\
\hline Gubeng & 16740 & 1230 & 82 & 80 \\
\hline Rungkut & 5142 & 930 & 70 & 71 \\
\hline Tenggilis & 10056 & 763 & 80 & 75 \\
\hline Gunung Anyar & 5587 & 695 & 82 & 61 \\
\hline Sukolilo & 4498 & 820 & 77 & 70 \\
\hline Mulyorejo & 12045 & 697 & 73 & 71 \\
\hline Sawahan & 23738 & 850 & 61 & 72 \\
\hline Wonokromo & 11166 & 825 & 71 & 71 \\
\hline Karangpilang & 7669 & 606 & 70 & 64 \\
\hline Dukuhpakis & 5900 & 678 & 59 & 72 \\
\hline Wiyung & 5403 & 833 & 71 & 77 \\
\hline Gayungan & 7311 & 1032 & 90 & 65 \\
\hline Wonocolo & 11590 & 1265 & 76 & 71 \\
\hline Jambangan & 11621 & 957 & 73 & 61 \\
\hline
\end{tabular}

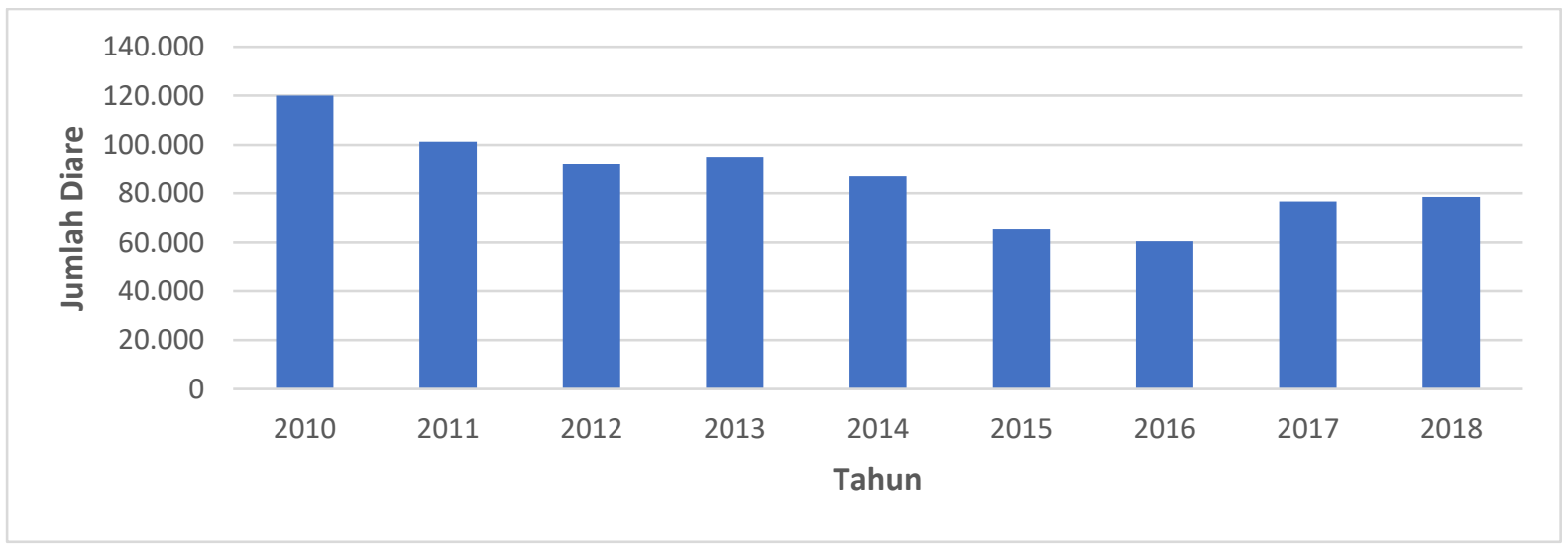

Gambar 3. Diare di Kota Surabaya

Analisis Deskriptif yang di lakukan dari tahun 2010 sampai dengan 2018 di Kota Surabaya terdapat tren penurunan sampai dengan tahun dimana angka kejadian diare terendah di Kota Surabaya yaitu tahun 2016. Setelah itu tahun 2017 mulai terjadi peningkatan tren begitu juga tahun 2018. 


\section{Pengujian Asumsi Regresi Linier Berganda}

Syarat kelayakan model uji regresi yang pertama adalah model regresi dikatakan layak jika angka signifikansi pada ANOVA sebesar $<0.05$.

Kedua Predictor yang digunakan sebagai variabel bebas harus layak. Kelayakan ini diketahui jika angka Standard Error of Estimate < Standard Deviation .

Ketiga Koefesien regresi harus signifikan. Pengujian dilakukan dengan uji t. Koefesien regresi signifikan jika $t$ hitung $>t$ table (nilai kritis). Dalam IBM SPSS dapat diganti dengan menggunakan nilai signifikansi (sig) dengan ketentuan sebagai berikut: a) Jika sig < 0,05; koefesien regresi signifikan.b) Jika sig >0,05; koefesien regresi tidak signifikan.

Keempat tidak boleh terjadi multikolinieritas, artinya tidak boleh terjadi korelasi antar variabel bebas yang sangat tinggi atau terlalu rendah. Syarat ini hanya berlaku untuk regresi linier berganda dengan variabel bebas lebih dari satu. Terjadi multikolinieritas jika koefesien korelasi antara variable bebas $>0,7$ atau $<-0,7$.

Kelima Tidak terjadi Autokorelasi jika: $-2 \leq \mathrm{DW} \leq 2$.

Kenam Keselerasan model regresi dapat diterangkan dengan menggunakan nilai $r^{2}$ semakin besar nilai tersebut maka model semakin baik. Jika nilai mendekati 1 maka model regresi semakin baik. Nilai $r^{2}$ mempunyai karakteristik diantaranya: 1) selalu positif,2) Nilai $r^{2}$ maksimal sebesar 1. Jika Nilai $r^{2}$ sebesar 1 akan mempunyai arti kesesuaian yang sempurna. Maksudnya seluruh variasi dalam variabel tergantung (variabel Y) dapat diterangkan oleh model regresi. Sebaliknya jika $r^{2}$ sama dengan 0 , maka tidak ada hubungan linier antara variabel bebas (variabel $\mathrm{X}$ ) dan variabel tergantung (variabel $\mathrm{Y}$ ).

Ketujuh Terdapat hubungan linier antara variabel bebas $(\mathrm{X})$ dan variabel tergantung $(\mathrm{Y})$.

Kedelapan Data harus berdistribusi normal.

Kesembilan Data berskala interval atau rasio.

Kesepuluh Terdapat hubungan dependensi, artinya satu variabel merupakan variabel tergantung yang tergantung pada variabel (variabel) lainnya.

\section{Uji Normalitas}

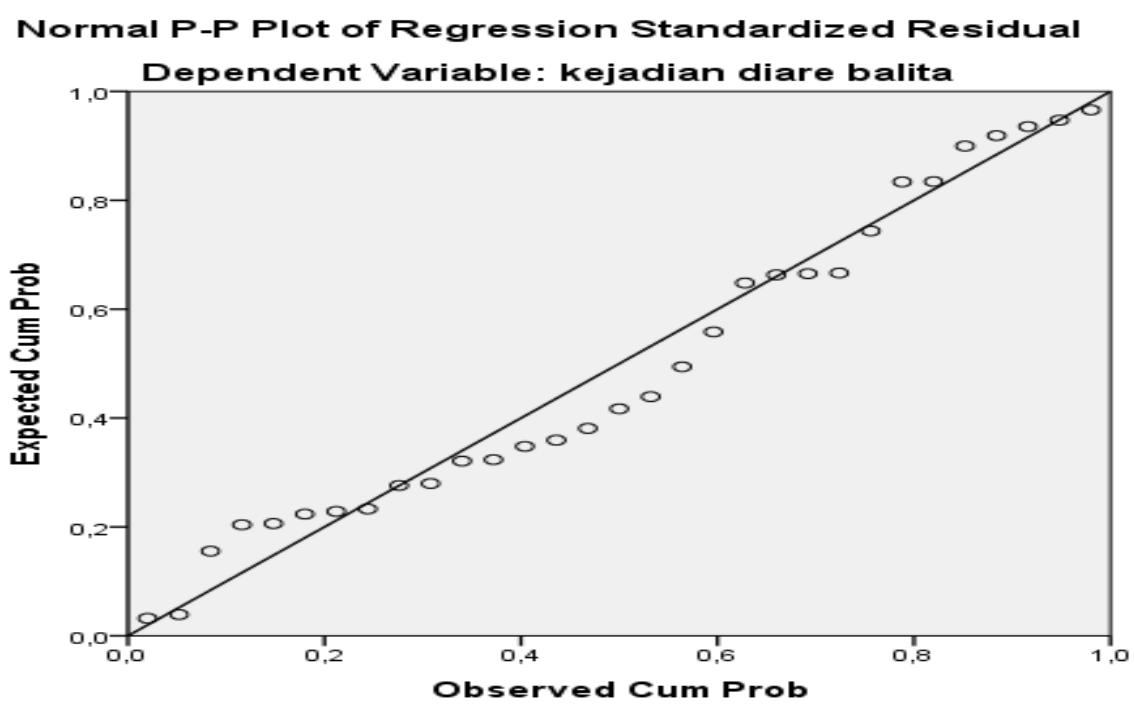

Gambar 3. Probability Plot

Model regresi memiliki distribusi data yang normal ini di tandai dengan data ploting (titik-titik/ lingkaranlingkaran) yang menggambarkan ditribusi data sesungguhnya mengikuti garis diagonal.

\section{Uji Multikolinearitas}

Tabel 2. Collinearity Statistics

\begin{tabular}{cc}
\hline Tolerance & VIF \\
\hline, 883 & 1,133 \\
, 942 & 1,062 \\
, 836 & 1,196 \\
\hline
\end{tabular}


Model regresi ini tidak terjadi Multikolinearitas karena nilai Tolerance lebih besar dari 0,1 dan ni lai VIF tidak lebih dari 10 .

\section{Uji Heteroskedastistias}

Model regresi ini juga tidak terlihat gejala terjadinya Heteroskedastistias, dikarenakan tidak ada pola yang jelas pada plot skater plot(Gambar.4), serta titik-titk / lingkaran menyebar diatas dan di bawah angka 0 pada sumbu Y.

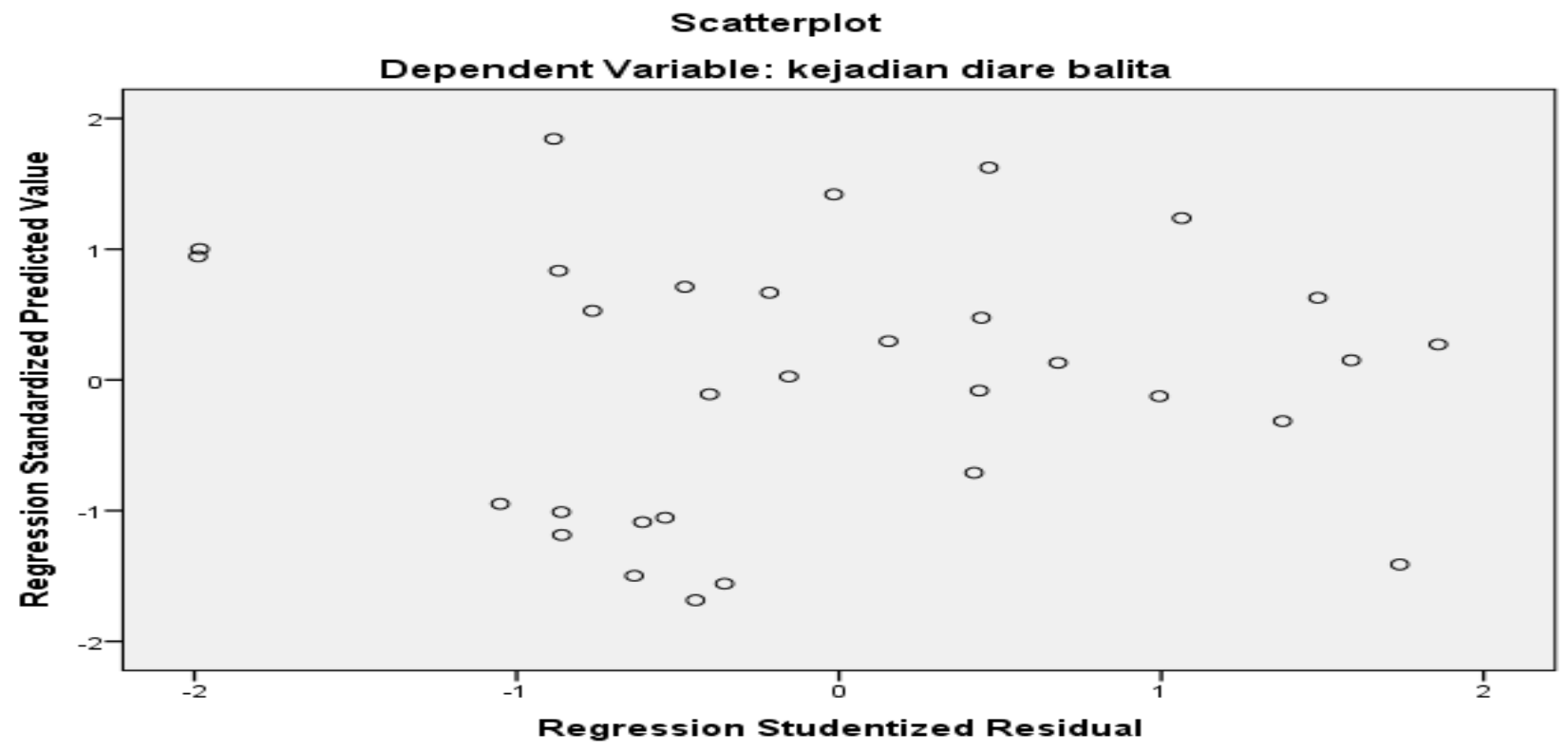

Gambar 4. Scatterplot

\section{Analisis Korelasi Ganda (R)}

Menurut Sugiyono (2006) pedoman untuk memberikan interpretasi koefisien korelasi sebagai berikut:
$0,00-0,199$
$0,20-0,399$
$=$ sangat rendah
$=$ rendah
$0,40-0,599 \quad=$ sedang
$0,60-0,799=$ kuat
$0,80-1,000=$ sangat kuat

Hasil analisis regresi, dilihat pada output moddel summary dan disajikan sebagai berikut:

Tabel 3. Analisis Korelasi Ganda

\begin{tabular}{rc}
\hline $\mathbf{R}$ & Adjusted R Square \\
\hline 0,65 & 0,36 \\
\hline
\end{tabular}

Dapat di ketahui dari model sumary tabel 3, R memiliki nilai 0,65 yang artinya hubungan antara kepadatan penduduk, Asi Eksklusif dan PHBS memiliki hubungan dengan tingkat "sedang" terhadap kejadian diare balita di surabaya. Kolom selanjutnya pada tabel Model Summary adalah ajdusted R square yaitu $\mathrm{R}$ yang sudah di sesuaikan, nilainya 0,36 atau $36 \%(0,36 \times 100 \%)$ memperlihatkan tingkat hubungan antara kepadatan penduduk ,Asi Eksklusif dan PHBS memiliki hubungan dengan tingkat "rendah" terhadap kejadian diare balita di surabaya .

\section{Uji Koefisien Regresi Secara Bersama-sama (Uji F)}

Uji ini digunakan untuk mengetahui apakah variabel independen $\left(\mathrm{X}_{1}, \mathrm{X}_{2} \ldots \mathrm{X}_{\mathrm{n}}\right)$ secara bersama-sama berpengaruh secara signifikan terhadap variabel dependen $(\mathrm{Y})$.

Tabel 4. Tabel Uji Secara Bersama-sama

\begin{tabular}{cl}
\hline Model & Sig. \\
\hline Regression & 0,01 \\
\hline
\end{tabular}


Tertera nilai signifikansi(sig.) pada tabel 4 sebesar 0,01 maka kita bisa menyimpulkan bahwa variabel kepadatan penduduk, Asi Eksklusif dan PHBS berpengaruh secara bersama-sama terhadap kejadian diare pada balita . Hal ini dengan mengikuti taraf signifikansi (sig.) 0,05 sebagai nilai patokan untuk nilai signifikansi. Artinya jika nilai probabilitas (signifikansi) dibawah 0,05 maka seluruh variabel independen berpengaruh terhadap variabel dependen.

\section{Uji Koefisien Regresi Secara Parsial (Uji t)}

Tabel 5. Tabel Uji Secara Parsial

\begin{tabular}{lcc}
\hline & Model & Sig. \\
\hline Kepadatan_Penduduk & & 0,099 \\
Asi_Exklusif & & 0,006 \\
Rumahtangga_BerPHBS & 0,432 \\
\hline
\end{tabular}

Uji ini digunakan untuk mengetahui apakah dalam model regresi variabel independen $\left(\mathrm{X}_{1}, \mathrm{X}_{2}, \ldots . . \mathrm{X}_{\mathrm{n}}\right)$ secara parsial berpengaruh signifikan terhadap variabel dependen (Y). Tertera nilai signifikansi(sig.) kepadatan penduduk sebesar 0,099 maka lebih besar dari nila 0,05 yang memiliki arti nonsignifikan ,kemudian Asi Eksklusif memiliki nilai sebesar 0,006 maka lebih kecil dari nila 0,05 yang berarti juga memiliki nilai signifikan, penelitian lain yang di lakukan oleh Racita Melvani dengan variabel Asi Eksklusif terhadap kejadian diare di daerah kertajaya Kota Palembang memberikan kesimpulan variabel Asi Eksklusif bernilai signifikan (Melvani, Zulkifli and Faizal, 2019). Variabel rumah tangga ber-PHBS bernilai 0,432 yang berarti lebih besar dari 0,05 atau nonsignifikan. Penelitian lain yang di lakukan oleh Hilda Irianty, dkk. PHBS di analisis per item yaitu pemberian ASI eksklusif, hubungan antara penimbangan balita, penggunaan air bersih, penggunaan jamban sehat, cuci tangan pakai sabun (Irianty, Hayati and Riza, 2018), karena keterbatasan data dalam penelitian ini PHBS di jadikan menjadi variabel. Dapat di tarik benang merah bahwa variabel Asi Eksklusif berpengaruh secara parsial terhadap kejadian diare pada balita. sedangkan rumah tangga ber-PHBS dan Kepadatan penduduk tidak memiliki pengaruh secara parsial terhadap kejadian diare balita di surabaya. Hal ini dengan mengikuti taraf signifikansi (sig.) 0,05 sebagai nilai patokan untuk nilai signifikansi.

Berdasarkan tabel uji di atas antara variabel independen dan dependen mempunyai nilai pengaruh sebesar 36\%. variabel kepadatan penduduk, Asi Eksklusif dan PHBS berpengaruh secara bersama-sama terhadap kejadian diare pada balita. kemudian hubungan parsial variabel Asi Eksklusif berpengaruh terhadap kejadian diare pada balita secara parsial. sedangkan PHBS dan kepadatan penduduk tidak memiliki pengaruh secara parsial terhadap kejadian diare balita di surabaya.

Teori Hendrik L. Blum, kejadian penyakit di masyarakat dipengaruhi oleh empat faktor, yaitu faktor genetik, faktor lingkungan, faktor pelayanan kesehatan dan faktor perilaku (Raksanagara and Raksanagara, 2015). Kota Surabaya sendiri Perilaku Hidup Bersih dan Sehat masyarakat yang bertempat tinggal di surabaya sudah baik. Hal ini di buktikan dengan angka cakupan presentase rumah ber PHBS di Kota Surabaya rata- rata sebanyak 69\% warga sudah menerapkan karena Perilaku Hidup Bersih dan Sehat (Dinkes Kota Surabaya, 2015).

Penelitian yang dilakukan oleh Imelda Mohamad, Tahir Abdullah, Leo Prawirodiharjo pada tahun 2014, memberikan kesimpulan diare termasuk empat penyebab utama kematian anak dibawah usia lima tahun di negara berkembang termasuk Indonesia, tingginya angka kesakitan dan kematian bayi di Indonesia terkait dengan kemampuan seorang ibu dalam pemberian Air Susu Ibu (ASI) yang tidak memadai kepada bayinya (Mohamad, Abdullah and Prawirodiharjo, 2014). Asi Eksklusif erat hubunganya dengan setatus gizi balita, di surabaya sendiri prevalensi gizi buruk terjadi penurunan dari tahun ke tahun mulai dari tahun 2016 sebanyak 0,158\% kemudian di tahun 2017 sebanyak 0,150\% dan di tahun 2018 sebanyak 0,14\% (Dinkes Kota Surabaya, 2015).

Pada uji statistik Asi Eksklusif mempunyai nilai B = 16,033 yang artinya setiap penambahan 1\% ibu yang memberikan Asi Eksklusif pada balitanya maka akan menambah balita yang kebal terhadap diare sebanyak 16 balita atau mengurangi angka kejadian diare pada balita sebanyak 16 balita (dibulatkan), maka dari itu program Dinas Kesehatan Surabaya untuk penggalakan untuk memperbanyak terbentuknya kampung Asi Eksklusif dinilai sudah tepat guna. Penelitian lain yang juga meneliti tentang diare dan Asi Eksklusif, dilakukan oleh Hasnatul Huda dan Atus Amadi Putrala bahwa Variabel-variabel bebas yang paling berpengaruh terhadap kejadian Diare pada balita adalah selain Umur Balita juga pemberian Asi Ekslusif (Huda and Putra, 2017).

Penelitian yang di lakukan oleh Amalia memberikan kesimpulan hubungan antara kepadatan penduduk, secara spasial mengindikasikan adanya pengaruh antara variabel tersebut dengan kejadian diare (Amalia, 2012), berdasarkan penelitian lain kepadatan penduduk mempengaruhi tingkat terjadinya diare karena jarak antara septictank dan sumber air kurang dari 10 meter.(Purwanto, 2017) daerah perkotaan selalu mempunyai kepadatan penduduk di atas rata rata ,hal ini tak bisa di pungkiri karena laju pertumbuhan dari tahun ke tahun di kota 
semakin tinggi. menurut survei yang di lakukan BPS, terdapat peningkatan jumlah penduduk yaitu dari tahun 2015 sebanyak 2.771.615 penduduk kemudian pada 2016 sebanyak 2.862 .406 penduduk dan 2017 sebanyak 2.874.699 penduduk.(BPS, 2018) meski demikian kepadatan penduduk tidak memiliki pengaruh terhadap kejadian diare pada balita di surabaya, salah satu faktor yang menjadikan kepadatan penduduk tidak memiliki pengaruh hal ini karena Surabaya merupakan salah satu kota besar di Indonesia yang memiliki tata ruang kota bagus dan memperoleh berbagai penghargaan. Salah satu penghargaan yang diperoleh oleh Kota Surabaya adalah Adipura Kencana yaitu sebagai kota metropolitan paling bersih di Indonesia sebanyak 8 kali berturutturut (Pipit, 2019).

Meskipun begitu untuk wilayah Surabaya karena memiliki kepadatan penduduk cukup tinggi maka harus tetap konsisten untuk melakukan pemeriksaan rutin terhadap sarana sanitasi yang ada untuk mencegah terjadinya penularan penyakit dan mempertahankan capaian yang ada. Dalam hal ini seperti bekerjasama dengan tokoh masyarakat atau kader. Pada musim penghujan atau musim kemarau pihak Puskesmas dari bidang Pengelola Program P2 diare dan kesling sebaiknya bekerjasama dengan masyarakat untuk selalu mencegah masalah yang mungkin akan menyebabkan diare dengan cara membersihkan tempat-tempat yang mungkin menyebabkan terjadinya diare atau suatu penyakit yang lain.

\section{KESIMPULAN}

Kepadatan penduduk tidak mempengaruhi kejadian diare pada balita di surabaya pada tahun 2018, salah satu faktor yang mempengaruhi hal ini karena Surabaya merupakan salah satu kota besar di Indonesia yang memiliki tata ruang kota bagus dan memperoleh berbagai penghargaan. Salah satu penghargaan yang diperoleh oleh Kota Surabaya adalah Adipura Kencana sebagai kota metropolitan paling bersih di Indonesia sebanyak 8 kali berturut-turut(Pipit, 2019) Asi Eksklusif mempengaruhi kejadian diare pada balita di surabaya pada tahun 2018, setiap penambahan 1\% dari total ibu yang memberikan Asi Eksklusif pada balitanya di Kota Surabaya maka akan mengurangi angka kejadian diare pada balita sebanyak 16 balita. Rumah tangga ber PHBS tidak mempengaruhi kejadian diare pada balita di surabaya pada tahun 2018, di sebabkan Perilaku Hidup Bersih dan Sehat masyarakat yang bertempat tinggal di surabaya sudah cukup baik yaitu rata- rata cakupan Rumah tangga yang melakukan PHBS sebanyak 69\%.

\section{ACKNOWLEDGEMENT}

Penulis mengucapkan terima kasih kepada seluruh staf pengajar Fakultas Kesehatan Masyarakat Universitas Airlangga atas bimbingan dan bantuan selama pelaksanaan penelitian ini dan para pasien yang telah bersedia menjadi responden .

\section{DAFTAR PUSTAKA}

Amalia (2012) Analisis Spasial Kejadian Diare Di Wilayah Kerja Puskesmas Panunggangan Kecamatan Pinang Kota Tangerang Tahun 2009-2011. Universitas Indonesia.

Badan Pusat Statistik Provinsi Jawa Timur (2019) Jumlah Kasus Penyakit Menurut Kabupaten/Kota dan Jenis Penyakit di Provinsi Jawa Timur, 2018, 09 Oktober 2019.

BPS (2018) Jumlah Penduduk dan Laju Pertumbuhan Penduduk Menurut Kabupaten/Kota di Provinsi Jawa Timur, 2010, 2016 dan 2017.

Dinas Kesehatan Kota Surabaya (2018) Profil kesehatan kota surabaya 2018. Edited by Pemerintah Kota Surabaya. Surabaya: Pemerintah Kota Surabaya.

Dinkes Kota Surabaya (2015) Profil Kesehatan Kota Surabaya 2015. Edited by Pemerintah Kota Surabaya. Surabaya: Pemerintah Kota Surabaya.

Huda, H. and Putra, A. A. (2017) 'Faktor-faktor yang Mempengaruhi Penyakit Diare Pada Balita di PuskesmasPasarBaru Dengan Pendekatan Analisis Regresi Logistik', Seminar Nasional Pendidikan, Sains dan Teknologi, pp. 112-119.

Irianty, H., Hayati, R. and Riza, Y. (2018) 'Hubungan Perilaku Hidup Bersih dan Sehat (PHBS) Dengan Kejadian Diare Pada Balita', 8(April), pp. 1-10.

Melvani, R. P., Zulkifli, H. and Faizal, M. (2019) 'Analisis Faktor yang Berhubungan Dengan Kejadian Diare Balita di Kelurahan Karyajaya Kota Palembang', JUMANTIK (Jurnal Ilmiah Penelitian Kesehatan), 4(1), p. 57. doi: 10.30829/jumantik.v4i1.4052.

Mohamad, I., Abdullah, T. and Prawirodiharjo, L. (2014) 'Association Between Exclusive Breastfeeding And Diarrhea In Infants 0-11 Months In The Region Of Galesong Utara Health Centers', ilmu kesehatan, (8), pp. $1-15$.

Pipit (2019) 8 Kali Berturut-Turut Terima Adipura, Kota Surabaya Resmi Raih Penghargaan Tertinggi Adipura 
Kencana, Senin, 14 Januari 16:41.

Purwanto, E. (2017) 'Diarrhea Prevention in Children at the Dense Population Area in Malang', Ilmu Kesehatan, pp. 61-66.

Raksanagara, A. S. and Raksanagara, A. (2015) 'Perilaku Hidup Bersih dan Sehat Sebagai Determinan Kesehatan yang Penting pada Tatanan Rumah Tangga di Kota Bandung Determinant Health in Bandung', ilmu kesehatan masyarakat, 1(38), pp. 30-34. doi: https://doi.org/10.24198/jsk.v1i1.10340. Sugiyono (2009) Metode Penelitian Kuantitatif, Kualitatif dan R\&D. Bandung: Alfabeta.

Sutomo, B. (2010) Menu Sehat Alami untuk Batita dan Balita. Jakarta: Demedia.

United Nations (2015) 'Tujuan Berkelanjutan Pembangunan Yang Perlu Diketahui Oleh Pemerintah Daerah', 2015, March, p. 24. 